\title{
СИНТАКСИЧНІ РЕСУРСИ ДІАЛОГІЧНОЇ ОРГАНІЗАЦІЇ НАУКОВО-НАВЧАЛЬНИХ ТЕКСТІВ
}

Шабуніна В. В. Синтаксичні ресурси діалогічної організації науково-навчальних текстів.

У статті визначено й схарактеризовано основні синтаксичні засоби, які виконують когнітивну функцію, створюють комунікативний ефект внутрішньої діалогізації мовлення; збільшують інформативність науково-навчального тексту й реалізують загальну тенденцію до скорочення надлишковості в мові; забезпечують адекватний перлокутивний ефект.

Ключові слова: автор, адресат, діалогічність, синтаксичні засоби діалогічної організації, науковонавчальний текст.

Шабунина В. В. Синтаксические ресурсы диалогической организации научно-учебных текстов.

В статье указаны и охарактеризованы основные синтаксические средства, которые выполняют когнитивную функцию, создают коммуникативный эффект внутренней диалогичности речи; увеличивают информативность научно-учебного текста и реализуют общую тенденцию к сокращению избыточности в языке; обеспечивают адекватный перлокутивный эффект.

Ключевые слова: автор, адресат, диалогичность, синтаксические средства диалогической организации, научно-учебный текст.

Shabunina V. V. Syntactical means of dialogical organizing of scientific-educational texts.

The principal syntactical means implementing cognitive function, making communicative effect of internal speech dialogicity, increasing scientific-educational text informativity and tending to language redundancy reduction, ensuring adequate perlocutive effect are pointed out and characterized in the article.

Key words: an author, an addressee, dialogicity, syntactical means of dialogical organizing, a scientificeducational text.

Вивченню наукового стилю та його жанрів присвячені розвідки О. О. Баженової, Н. В. Ботвиної, М. Д. Гінзбурга, М. А. Жовтобрюха, М. М. Кожиної, М. П. Котюрової, С.В.Малихіної, А. Р. Медведєва, Н. Ф. Непийводи, Г. С. Онуфрієнко, П. О. Селігея, Л. В. Славгородської та інших дослідників, але засоби діалогічної організації жанрів науковонавчального підстилю ще не були об'єктом спеціального лінгвостилістичного дослідження. Стаття має на меті поглибити вивчення діалогічної організації наукового тексту, дослідити й схарактеризувати синтаксичні ресурси діалогічної структури науково-навчальних текстів технічної галузі.

Розвиненість мови, іiі функціонування в науковій сфері значною мірою зумовлені розвитком синтаксичної будови, оскільки синтаксис забезпечує втілення комунікативної та пізнавальної функцій мови. 
Експресивності висловлювання сприяють речення різної комунікативної спрямованості (питальні, спонукальні). У наукових текстах, зокрема навчальних посібників, значне емоційно-експресивне й інтелектуальне навантаження несуть окличні речення, які привертають увагу читачів. Інтерес адресата підтримується вираженням ставлення автора до змісту тексту як до чогось важливого. Висловлення емоцій привертає увагу слухача до предмета обговорення, посилює інтерес. Наприклад: Якщо ж система багатозадачна, то в пам'яті одночасно перебувають кілька програм, щуо повинні знаходитися за тією самою адресою! (ОС, 189).

Одним із прийомів реалізації авторської комунікативної стратегії $\epsilon$ діалог з читачем із використанням запитань. Наявність питальних речень передбачає безпосереднього адресата, отже, такі речення вживають у мовленні 3 метою діалогізації спілкування. Зміст питальних речень у текстах науково-навчального підстилю адресований читачеві, i вони вимагають певної відповіді. Подібну тактику автори використовують у посібниках і збірниках задач, щоб з'ясувати ступінь засвоєння студентами навчального матеріалу, активізувати їхню увагу: Чи залежать значення розмірів на кресленні від його масштабу? (ІКГ, 91).

Діалогічність спілкування зі студентами виявляється в побудові науково-навчального тексту у вигляді міркувань автора. Таким способом автор, уводячи субтекст нового знання, відтворюючи в тексті процес наукового дослідження, залучає адресата до формулювання нових наукових ідей. Авторською інтенцією є демонстрація адресатові алгоритму утворення наукової думки, наближення реципієнта до наукової творчості.

Задля адекватного комунікативного впливу на читача автор навчального посібника часто формулює питання, відповіді на які утворюють із ними єдність «питання - відповідь». На думку В.В. Одинцова, автор використовує спосіб психологічної зупинки, фіксації уваги читачів на важливому моменті [4, с. 14]. Наприклад: Що ж⿻ являс собою мікроядро? Аналогом мікроядра є набір функиій базового класу загального виду, застосовуваних в об'єктно-орієнтованому програмуванні (OC, 34). Крім того, розглянутий приклад свідчить про штучне створення діалогічного мовлення в тексті науково-навчального підстилю автором. Єдність «питання - відповідь» прогнозує питання читача, на які відповідає сам мовець. Отже, спостерігається явище автодіалогічності.

Діалогічній взаємодії зі студентами сприяє вибраний автором порядок слів у реченні. Для текстів науково-навчального підстилю нейтральним уважається прямий порядок слів. Щоб унести додаткові відтінки значення, підсилити виразність слів, зберігаючи основний зміст речення, автор використовує інверсію: Для побудови паралелограмів $\underline{\underline{\epsilon}} \underline{\underline{8 c i}}$ дані (IКГ, 37).

За В. І. Кухарєвою [2], одним із засобів забезпечення комунікативно- 
пізнавальних потреб спілкування в науковій сфері є односкладні речення. У науково-навчальному підстилі такі речення максимально неупереджено, без вказівки на дійову особу відтворюють навколишню дійсність, що відповідає основній комунікативній інтенції автора наукового стилю в цілому - віддзеркалення наукової картини світу в об’єктивній і узагальненій формі. Зібраний фактичний матеріал підтверджує, що в текстах підручників i навчальних посібників односкладні речення виконують важливі комунікативні функції, оптимізують спілкування, забезпечують діалогічність і сприяють реалізації когнітивної функції.

Використовуючи односкладні означено-особові речення, автор основну увагу зосереджує на виділенні семантики дієслова, що надає висловленню виразності, динамічності, активізує увагу читача, спонукає до спільних дій, забезпечує наочність викладу. Уявімо изиліндр paдіуса $R$ та висоти як стрижневу конструкиію <...> (ІКГ, 107-108).

Задля ефективного комунікативного впливу на читача автор використовує прийом діалогізації, що становить прихований у тексті діалог, виражений у формі безпосереднього звертання автора до читача, наприклад у формі спонукальних речень: Визначте серію з'єднання та товщину зубиів (рис. II.113) (ІКГ, 89).

Для забезпечення діалогічності науково-навчального тексту, автор використовує неозначено-особові конструкції, які зосереджують увагу на основних моментах змісту, зокрема на дії, описують закономірності, загальновідомі факти та явища певної науки, слугують рекомендацією для здійснення тієї чи тієї операції: Механічним способом вологу відділяють у пресах або изентрифугах (Т, 375).

Дослідивши тексти підручників і навчальних посібників, можемо стверджувати, що високий комунікативний потенціал мають безособові речення. Загальновідомо, що безособові речення позначають дію людей взагалі або їх невизначеної кількості; спрямовують увагу читача на об'єкт або дію; виражають некатегоричність викладу. Наприклад: Аналогічний спосіб закріплення <..> використовують для протяжок $i$ секцій, коли гвинти не вдається розмістити знизу (MI, 126).

Реалізуючи комунікативний намір, автор застосовує предикативні форми на -но, -mo, які виражають категоричність повідомлення. Крім цього, вони усувають з викладу суб'єкт дії; акцентують увагу адресата на об'єкті або дії: На рис. 4.1 зображено прочес пароутворення 1кг води в рv-координатах при $p=$ const $(\mathrm{T}, 51)$.

Інфінітивні речення теж характеризуються певною комунікативною завантаженістю. Такі конструкції як засоби реалізації комунікативної стратегії автора активізують увагу читача, спонукають до дії: Якщо підставити в формулу (2.4) замість v ї̈ значення, виражені через $n$, то отримаємо $\Delta v=n-n_{3} / n=1-n_{3} / n(2.5)$ (РКМB, 38).

За допомогою номінативних речень автор організовує процес 
сприймання тексту адресатом, поділяє інформацію на основну й допоміжну, реалізує зв'язність викладу: Рис. 1.9 Оболонковий кузов легкового автомобіля (ТОР, 25).

Реалізуючи загальну тенденцію до скорочення надлишковості в мові, автори підручників і навчальних посібників широко використовують у текстах неповні речення. Неповнота граматичної структури таких речень не перешкоджає комунікативному процесу, оскільки пропуск тих чи тих членів не порушує їхньої змістової завершеності. Серед неповних речень у науково-навчальному підстилі переважають контекстуальні неповні речення $з$ пропущеними головними чи другорядними членами, які раніше були згадані в контексті: або в найближчих реченнях, або в цьому самому реченні (якщо воно складне), наприклад: Каркас кузова може виготовлятися зі стандартних профілів, а зовнішні панелі - зі итампувань нескладної форми (ТОР, 55).

Важливим комунікативним засобом у науково-навчальному підстилі слугують однорідні члени речення, за допомогою яких автор реалізує класифікаційну функцію, розмежовує родові й видові поняття, забезпечує оптимальне сприймання тексту адресатом, лінійно організовуючи мовлення. Цей засіб реалізації комунікативної авторської стратегії бере участь у вираженні наукової картини світу, зіставляючи явища дійсності: <..> відхилення для дрібних мітчиків встановлюють мени жорсткими, ніж для великих (MI, 235).

Задля семантичного й граматичного доповнення складу конкретного речення, своєрідного його розгортання автор використовує відокремлення. За допомогою такої тактики адресант звертає особливу увагу читача на певний член речення, підкреслює комунікативне призначення елементів висловлюваної думки. Щоб передати значення включення, виключення, заміщення, доповнення, автор вдається до використання відокремлених додатків - конструкцій із прийменниками крім, окрім, замість, за винятком, включаючи: Для оцінки термотрансформаторів, включаючи холодильні машини, можна користуватися такими показниками (Т, 266).

Відокремленою частиною в структурі простого речення автор завжди виразно актуалізує цей елемент думки. Крім того, вдаючись до відокремлення, автор посилює комунікативну гармонію сказаного, досягає певної економії у висловленні, словесно скорочує його, полегшуючи сприймання інформації.

Задля досягнення оптимального комунікативного ефекту автор спирається на фонові знання адресата при використанні обставин причини, умови, підстави умовиводу тощо (відокремлених і невідокремлених), виражених іменниками зі вторинними прийменниками згідно з, відповідно до, у зв'язку з, на відміну від, залежно від, завдяки, внаслідок. Наприклад: Відповідно до молекулярно-кінетичної теорії газів для одноатомних газів $k=1,667$, для двохатомних $k=1,4<\ldots>(\mathrm{T}, 22)$. 
Адресованість мовлення виявляється й у такому прийомі діалогічності, як перефразування думки. Щоб з'ясувати значення попередніх слів або дати іншу назву описуваному поняттю, автор починає сполучниками тобто, або (=тобто), а саме уточнювальні словосполучення: Густина вологого повітря, тобто суміші сухого повітря і водяної пари, дорівнює < .. > $(\mathrm{T}, 378)$.

Використовуючи відокремлені обставини, виражені дієприслівниковим зворотом, автор досягає певного перлокутивного ефекту, оскільки виступає коментатором свого висловлення, демонструє свою участь у виконанні дій, обчислень тощо: Користуючись зображенням ииклу в $T$-s-координатах, визначимо термічний ККД циклу Карно <...> (T, 40).

Писемне мовлення є усвідомлюваним процесом, який передбачає можливість попереднього обдумування, планування висловлення, його корекції, тому мовець завжди намагається висловитися стилістично правильно. Із цією метою автор текстів науково-навчального підстилю часто має комунікативну потребу у використанні вставних і вставлених слів, сполучень слів та речень, щоб передати читачеві додаткові, часто побіжні повідомлення, зауваження до того, що виражається членами речення в багатьох висловленнях. За допомогою вставних слів автор суттєво видозмінює зміст висловленого, допомагає читачеві сприйняти текст у прогнозований спосіб.

Щоб допомогти читачеві впорядкувати думки, пов'язати їх між собою, забезпечити послідовність викладу, автор використовує вставні слова отже, значить, нарешті, до речі, зокрема, наприклад, навпаки, однак, крім того тощо: Прямоточна схема, однак, забезпечує більш м'який режим нагрівання <...> $(\mathrm{T}, 171)$.

Метатекстові оператори, виражені словами категорії стану звичайно, очевидно, мабуть, дійсно, справді, напевно, автор використовує, щоб передати впевненість, невпевненість, передбачення, можливість, неможливість, вірогідність, сумнів тощо: Звичайно, кількість продуктів неповного горіння CO, NO невелика <..> (T, 201). Модальним словом мабуть автор висловлює певний сумнів у слушності висловлюваної думки, применшує ії категоричність, обов'язковість: < ..> мабуть, $d S$ відкритоі системи може мати будь-який знак або дорівнювати нулеві (T, 110).

Реалізуючи комунікативні інтенції, які полягають у наголошенні на ступені звичайності викладених фактів, автор використовує вставні слова 8 основному, як правило, головним чином: <..> тривалість горіння визначається, в основному, тривалістю горіння коксу $(\mathrm{T}, 196)$.

Вставні слова (словосполучення) автор використовує ще й для того, щоб виразити власні почуття, дати емоційну оцінку повідомлюваних фактів: На жаль, код, який формується обома трансляторами, не иілком сумісний (ОС, 409-410); наголосити на способі оформлення думки чи 
характері висловлювання: < ..> щуільність випромінювання, щуо проходить через границюю газового об’сму, строго говорячи, не пропориійна четвертому ступеню температури (Т, 164); вказати на джерело інформації: За даними ООН, від різних злакових рослин, вирощуваних на планеті, щзороку утворюється 1,7 млрд. $m$ соломи <..> (Т, 453); привернути, активізувати увагу читача: При бажжнні, маючи товщини пограничних шарів, параметри рідини $і$ величини теплових потоків на стіниі, можна обчислити локальні коефіціснти <...> $(\mathrm{T}, 152)$.

Задля передавання додаткових повідомлень, побічних зауважень, пояснення до якогось із членів речення чи речення загалом, яскравого підтвердження висловленої думки новими варіантами особливих сприймань, оцінок, зіставлень, спостережень, уточнень автор використовує вставлені конструкції. Ці елементи політекстуальної структури тексту надають викладові переконливості, регулюють процес сприймання, акцентують увагу на основних моментах змісту, пояснюють, привертають увагу до повідомлення. Наприклад: Точка $F$, симетрична точцуі $A$ відносно прямої $x=6$, має координати [див. (21.31)] < .. > (IКГ, 109).

У науково-навчальних текстах автори часто використовують іменникові особово-вказівні займенники він, вона, воно, вони та прикметникові вказівні займенники цеей, той, такий, що вживаються замість назв істот, предметів, явищ, ознак, згадуваних, як правило, раніше. Як зауважує Г.В. Волчанська, «наявність прономінативних субстантивів, зокрема особово-вказівних, у структурі простого неускладненого речення $\epsilon$ ознакою його синсемантичності, а отже, й залежності від попереднього або наступного контексту» [1, с. 100].

Звертаючи увагу адресата на лівобічний контекст, тобто використовуючи синтаксичну анафору, автор тим самим досягає комунікативного ефекту внутрішньої діалогізації мовлення: Теплова ізоляція - важливий елемент теплопроводів. Вона служить для зниження теплових втрат <..> $(\mathrm{T}, 366)$.

Маючи близьку комунікативну інтенцію, автор науково-навчального тексту використовує синтаксичну катафору, скеровуючи увагу адресата до правобічного (наступного) контексту, наприклад: Якщз температура точки тіла незмінна в часі й однакова на всій поверхні, то гранична умова виражається так: $t(P, r)=$ const $<\ldots>(\mathrm{T}, 119)$.

Для привернення уваги до повідомлюваного автор розчленовує цілісну змістово-синтаксичну структуру на інтонаційно та пунктуаційно ізольовані комунікативні частини (окремі речення), використовуючи синтаксичний прийом парцеляції. За допомогою парцельованих конструкцій реалізують у тексті змістопідсилювальну й ритмомелодійну функції. Парцелят стає комунікативно самостійним і цим привертає до себе увагу читача, ніби виділяючись із рівного ритму [3, с. 369].

У науково-навчальному підстилі прийом парцеляції допомагає 
забезпечити ефект невимушеності, спонтанності спілкування. У текстах підручників і навчальних посібників автор використовує парцеляцію ще й для конкретизації змісту базової частини вислову, для зображення обставин дії, актуалізації окремих деталей. Наближаються до парцельованих конструкції з протиставними сполучниками на початку самостійних речень: Ефективність перетворення теплоти в роботу характеризується термічним ККД. Однак термічний ККД циклу не відображає втрат, викликаних необоротністю реальних прочесів перетворення енергії (T, 47).

Аналіз синтаксичних особливостей науково-навчальних текстів свідчить про те, що частотні характеристики використання простих i складних речень у них майже однакові, 3 незначним переважанням складних. Це пов'язане з необхідністю вираження причинно-наслідкових, умовних, означальних, з'ясувальних та інших відношень. За висновком Н. В. Шульжук, «у діалогічному мовленні регулярно функціонують переважно елементарні складні речення, проте не є раритетними і складні багатокомпонентні конструкції» [5, с. 7].

Щоб наголосити на одночасності або послідовності дій чи явищ, виразити наслідкові відношення, автори підручників i навчальних посібників використовують складносурядні речення 3 єднальними сполучниками $i(\tilde{u})$, ma(=i), a(=i), а там, а потім, $і$ тому: Якщзо передні двері не відчиняються після натискання на кнопку ручки, то слід в отвір важеля встановити штовхач $і$ закріпити його фіксатор, а потім перевірити правильність регулювання штовхача (ТОР, 91).

Реалізуючи комунікативну інтенцію, яка полягає в протиставленні за змістом предикативних частин складносурядних речень, автор використовує сполучники а, але, та (=але), проте, зате, однак: Із таблиці виходить, щзо кращу завадостійкість має фазова модулячія, однак $і$ вона поступасться системам з оптимальним кодуванням (ОЦС, 401).

Задля забезпечення достатнього комунікативного впливу, адресант залучає парні градаційні сполучники не тільки... а $\check{u}$, не тільки... але $\check{u}$, не лиме... а $\check{\text {, }}$ не лиме... але $\check{u}$, які призначені для взаємного доповнення змісту предикативних частин: <..> не тільки починає відчуватися дискретна фотонна структура випромінювання, але й зумовлений цією причиною шум може перевищити всі інші перешкоди (ОЦС, 301).

Для вираження відношень несумісності, взаємовиключення та чергування дій або явищ мовець використовує складносурядні речення 3 розділовими сполучниками або, чи: Цей спосіб теплообміну використовується в тому випадку, коли недоцільно транспортувати гарячий теплоносій на великі відстані або коли неприпустимий безпосередній контакт гарячого і холодного теплоносіїв (Т, 168).

Маючи комунікативним наміром передавання уявному реципієнтові додаткового повідомлення, автор тексту науково-навчального підстилю 
використовує складносурядні речення 3 приєднувальним сполучником причому: Зони кузова, щзо деформуються, повинні поглинати кінетичну енергію удару під час зіткнення, причому ияя енергія має загаситися, пери ніж деформація дійде до салону (ТОР, 62).

Діалогічність спілкування зі студентською аудиторією виявляється в побудові тексту у вигляді міркувань автора - «розмови» із самим собою чи 3 читачами. У цій ситуації автор робить адресатів співучасниками створення певної концепції, оскільки вони простежують хід руху думки. Ця стратегія передбачає використання складнопідрядних речень нерозчленованої структури 3 підрядним 3'ясувальним, причому носієм основного змісту речення виступає саме підрядна частина: Із табл. 11.9 виходить, щцо процес декодування за всіма розрядами кодів з подвоєнням елементів опишеться логічними рівнями <...> (ОЦС, 426).

Задля досягнення максимального перлокутивного ефекту, автори технічних текстів науково-навчального підстилю надають перевагу складнопідрядним означальним реченням, складним багатокомпонентним реченням з різними типами зв'язку.

Для доведення висунутих тверджень, теорем, яке вимагає експлікації прийомів і стратегії аргументації, пояснень, процедур обгрунтування понять i способів їх розвитку автор науково-навчального тексту використовує підрядні речення, що виражають відношення причини, мети, місця, часу, а також наслідкові, умовні відношення зі сполучниками (сполучними словами): бо, тому щзо, через те щзо, щзоб, для того щзоб, де,

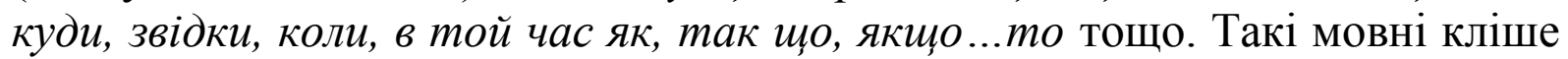
регулюють діалог автора 3 уявним адресатом, спрямовують виклад матеріалу. Наприклад: Щоб запобізти корозї панелі підлоги, слід періодично виймати килимки підлоги з кузова <..> (ТОР, 89) (підрядне мети); <..> величина $\varepsilon_{\Gamma}$ у цььому рівнянні сильно залежить від температури, так щзо щільність випромінювання <... не пропорційна четвертому ступеню температури (T, 164) (підрядне наслідку).

У науково-навчальному підстилі спостерігається використання підрядних допустових речень, якщо авторською інтенцією $є$ привернення уваги читачів до факту, всупереч якому відбувається дія головної частини: Хоча робота L $\mathrm{i}$ кількість теплоти $Q$ мають розмірність енергї, вони не є видами енергї $(\mathrm{T}, 19)$.

Прагнучи акцентувати посилення чи послаблення ознаки, автор використовує підрядні порівняльні речення 3 подвійним порівняльним сполучником чим...тим: <..> чим точніші методи розрахунку, тим меншим може бути коефіuуєнт запасу (ПМ, 22).

Задля передавання додаткового повідомлення, зауваження 3 приводу висловленого в головній частині автор використовує складнопідрядні речення з підрядними супровідними. Підрядна частина таких речень може виражати також суб'єктивно-оцінне ставлення до змісту висловленого в 
головній частині та висновки, що випливають з неї. Наприклад: Конденсат проходить через дросельний клапан 4, у результаті чого тиск його знижсується від р до $p_{1}(\mathrm{~T}, 102)$.

Авторське висловлення може замінюватися такими інтертекстуальними засобами, як цитата, покликання, у яких при відсутності прямої вказівки на автора публікації виклад позиції автора досягається шляхом його приєднання до думки автора цитати, визнаного авторитету. Наприклад: Робочою множиною називають множину сторінок, яка використовується програмою [10] (ОС, 199).

Членування тексту на абзаци як компоненти політекстуальної структури тексту робить композиційно-синтаксичну структуру зрозумілою, полегшує сприйняття навчального матеріалу. Ставлення автора до описуваних явищ імпліцитно передається в поділі на абзаци, який може виконувати не тільки логічну, а й експресивну функцію. Короткі речення, виділені в окремі абзаци, виконують функцію організації читання. Оптимального комунікативного впливу на адресата автор досягає, виділяючи абзацом фрагменти, які додають модальне значення.

Прагнучи досягти оптимального комунікативного впливу, автор нерідко сполучає абзацне членування тексту з нумерацією - цифровим чи буквеним позначенням послідовності розташування складників тексту. Традиційна система нумерації може доповнювати абзацне членування тексту, наприклад, при перерахуванні тез, пунктів правил тощо.

Отже, синтаксичні ресурси діалогічної організації науковонавчальних текстів відрізняються багатством і різноманітністю, оскільки синтаксис - це рівень мовної системи, який безпосередньо пов'язаний із процесом комунікації. За допомогою синтаксичних ресурсів діалогічної організації автор науково-навчальних текстів розмежовує основну та другорядну інформацію, забезпечує послідовність викладу, доводить висунуті твердження, що вимагає експлікації прийомів i стратегії аргументації, пояснень тощо; вносить додаткові відтінки значення й підсилює виразність семантики слів; передає більший чи менший ступінь категоричності викладу; підтверджує висловлену думку новими варіантами особливих сприймань, оцінок, зіставлень, уточнень; виражає суб'єктивно-оцінне ставлення щодо висловленого в тексті; формулює найбільш суттєві висновки. Це забезпечує оптимальне сприймання тексту адресатом, встановлення більш тісного контакту із читачем, дає можливість з’ясувати ступінь засвоєння студентом навчального матеріалу й залучати адресата до висування нових наукових ідей.

\section{Література}

1. Волчанська Г. Текстотвірні властивості займенникових іменників / Г. Волчанська // Наукові записки. - Випуск 73. - Серія : Філологічні науки (мовознавство) : у 2-х ч. - Кіровоград : РВВ КДПУ ім. В. Винниченка, 2007. - Ч. 2. - С. 99-108.

2. Кухарєва В. І. Комунікативний потенціал односкладних речень у науковому тексті (на матеріалі науково-технічної літератури) : автореф. дис. на здобуття наук. ступеня канд. філол. наук : 10.02 .01 «Українська мова» / В.І. Кухарєва / Інститут укр. мови НАН України. - К., 2003. - 20 с. 
3. Мацько Л. І. Стилістика української мови : [підруч.] / Л. І. Мацько, О. М. Сидоренко, О. М. Мацько; за ред. Л. І. Мацько. - К. : Вища шк., 2003. - 462 с.

4. Одинцов В. В. Стилистический анализ публичного выступления / В. В. Одинцов. - М. : Знание, 1973. $-56 \mathrm{c}$.

5. Шульжук Н. В. Структура складного речення у діалогічному мовленні (на матеріалі художніх творів) : автореф. дис. на здобуття наук. ступеня канд. філол. наук : 10.02.01 «Українська мова» / Н.В. Шульжук / Київський ун-т імені Тараса Шевченка. - К., 1999. - 16 с.

\section{Список використаних джерел}

ІКГ - Збірник задач $з$ інженерної та комп’ютерної графіки : [навч. посіб.] / В. Є. Михайленко, В. М. Найдиш, А. М. Підкоритов, І. А. Скидан ; за ред. В. Є. Михайленка. - К. : Вища шк., 2003. - 159 с.

МІ - Кукляк М. Л. Металорізальні інструменти. Проектування : [навч. посіб.] / М. Л. Кукляк, I. С. Афтаназів, I. І. Юрчишин. - Львів : Вид-во Національного університету «Львівська політехніка», 2003. $-556 \mathrm{c}$

ОС - Бондаренко М. Ф. Операційні системи : [навч. посіб.] / М. Ф. Бондаренко, О. Г. Качко. - Х. : Компанія СМIT, 2008. - 432 с.

ОЦС - Основи цифрових систем : [підруч.] / І. П. Барбаш, М. П. Благодарний, В. Я. Жихарев, В. М. Ілюшко, В. С. Кривцов, П. М. Куліков, М. В. Нечипорук, . М. Тимонькін, В. С. Харченко. Харків : Нац. аерокосмічний ун-т «Харк. авіац. ін-т», 2002. - 672 с.

ПМ - Гуліда Е. М. Прикладна механіка : [підруч.] / Е. М. Гуліда, Л. Ф. Дзюба, І. М. Ольховий ; за ред. Е. М. Гуліди. - Львів : Світ, 2007. - 384 с.

РКМВ - Бочков В. М. Розрахунок та конструювання металорізальних верстатів: [підруч.] / В. М. Бочков, Р. І. Сілін, О. В. Гаврильченко ; за ред. Р. І. Сіліна. - Львів : «Бескид Біт», 2008. - 448 с.

Т - Теплотехніка : [підруч.] / Б. Х. Драганов, А. А. Долінський, А. В. Міщенко, Є. М. Письменний ; за ред. Б. Х. Драганова. - Київ ; «НКОС», 2005. - 504 с.

ТОР - Бабіч Б. С. Технічне обслуговування й ремонт металевих кузовів автомобілів : [підруч.] / Б. С. Бабіч, В. В. Лущик. - К. : Либідь, 2001. - 460 с. 